\author{
M.J. Kvashnin ${ }^{1}$, I.S. Bondar ${ }^{*}$, D.T. Aldekeyeva ${ }^{1}$, H.С. Имамбаев ${ }^{2}$ \\ ${ }^{1}$ Academy of Logistics and Transport, c. Almaty, Kazakhstan \\ ${ }^{2}$ North Kazakhstan University named after M. Kozybaeva, Petropavlovsk, Kazakhstan
}

\author{
Information about the authors: \\ Kvashnin Mikhail Yakovlevich - Candidate of Technical Sciences, Professor, Academy of Logistics and Transport, \\ Almaty, Kazakhstan \\ https://orcid.org/0000-0002-3969-9299, e-mail: kvashnin_mj55@mail.ru \\ Bondar Ivan Sergeevich - Candidate of Technical Sciences (HAC RF), Ph.D (MES RK), Associate Professor ALiT, \\ Academy of Logistics and Transport, Almaty, Kazakhstan \\ https://orcid.org/0000-0001-7376-5643, e-mail: ivan_sergeevich_08@mail.ru \\ Aldekeyeva Dinara Tanashbekovna - Candidate of Technical Sciences, Associate Professor, Academy of Logistics and \\ Transport, Almaty, Kazakhstan \\ https://orcid.org/0000-0001-7376-5643, e-mail: aldekeeva69@mail.ru \\ Imambaev Nurlan - Master of Technical Sciences, Senior Teacher, North Kazakhstan University named after M. \\ Kozybaeva, Petropavlovsk, Kazakhstan \\ https://orcid.org/0000-0003-3104-8878, e-mail: imambaevn@mail.ru
}

\title{
METHOD OF HARDENING OF NON-RIGID ROAD CLOTHES
}

Annotation. The article discusses the method of strengthening the subgrade and non-rigid road pavements, in areas with weak soils. The use of geo-synthetic materials has a positive effect on the condition of the roadbed and pavement, especially in the conditions of the increased traffic load in recent years. The work performed allows us to reduce the cost of operating highways, since the construction of the pavement will last longer when used in the difficult natural and climatic conditions of our country.

Keywords: polymer geogrids, design and construction technology of road surfaces.

\section{Introduction}

Design solutions for road reinforcement. Reinforcement is used in new construction and in cases where it is planned to replace the existing road surface (Figure 1a), as well as in areas of widening of highways (Figure 1b). The geogrid is placed on the contact between the bearing layer of the base of untreated granular materials and the sandy additional layer of the base or the ground of the roadbed in the absence of road surfaces with improved types of coating (Figure 1c). For road surfaces with a transitional type of coating, a geogrid is placed under a coating of granular materials (Figure 1d). 


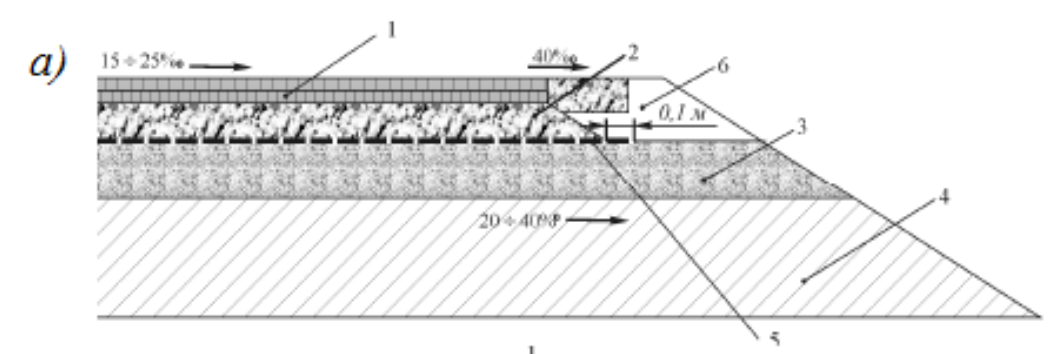

b)
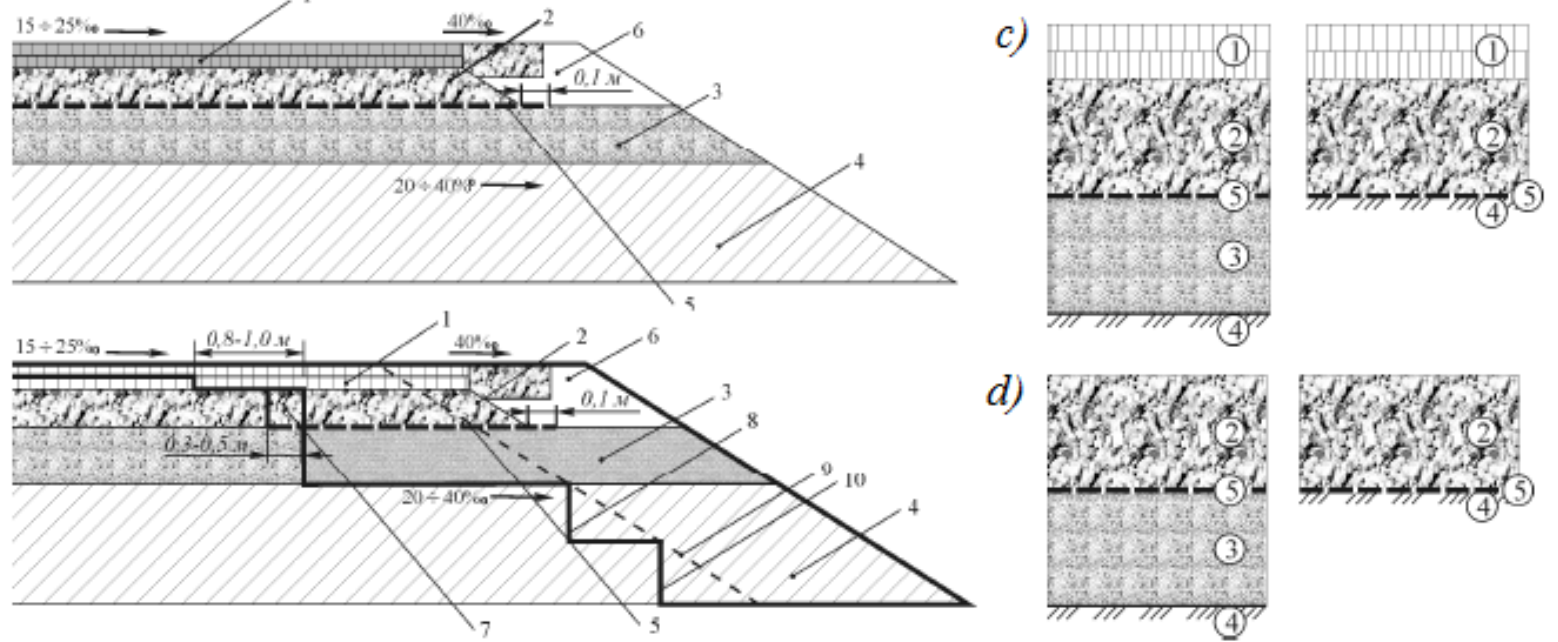

Fig. 1 - Reinforcement of the bases of road clothes in new construction (a), the execution of works for the widening of (b), design of reinforced pavements improved (c) and transitional (d) types: 1 - asphalt concrete pavement, 2 - gravel base, 3 - sand drainage layer, 4 - the soil subgrade,

5 - geogrid, 6 - cohesive soil on the roadside, 7 - podlaska edges of the base, 8 - outline of widening a, 9 - outline of the old slope, 10-ledges [6].

The decision on reinforcement is made taking into account the area of rational use of geogrids, the following additional provisions:

- it is recommended to use geogrids under the load-bearing bases of capital road coverings for roads with heavy and heavy traffic;

- it is recommended to use geogrids in transitional road coverings as a priority structure for stage construction.

In these cases, the determining factor for making a decision on the use of geogrids may be the performance of not only reinforcing functions, but also separation functions (preventing the interpenetration of materials of adjacent layers, leading to a decrease in the durability of the structure).

The choice of materials and the assignment of the thickness of the pavement layers is carried out taking into account the requirements of section 5 and on the basis of the calculation method according to clause 6.2 [1].

\section{Materials and methods}

Calculation of road surfaces based on the permissible pressure on the surface of the ground base. The construction of the road surface meets the requirements of strength if the condition is met:

$$
\sigma \leq \sigma_{\text {доп }}
$$

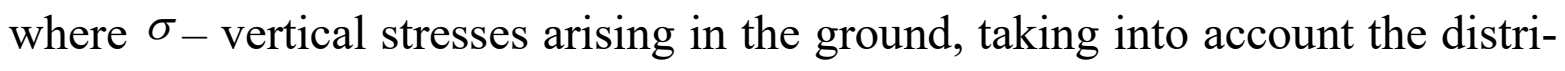
bution capacity of the road surface, $\mathrm{MPa} ;{ }^{\sigma_{\text {доn }}}$ - maximum permissible stress in the 
ground, at which the linear relationship between pressure and precipitation is maintained, MPa.

The effective vertical stresses are determined by the dependence:

$$
\sigma=\frac{P}{\omega}
$$

where $P$ - pressure on the coating from the design load, MPa; $\omega-$ a coefficient that characterizes the decrease in vertical stresses in the road surface and is determined by the dependence:

$$
\omega=1+a \cdot\left(\frac{h_{o d}}{D}\right)^{2} \cdot\left(\frac{E_{o d}}{E_{z p}}\right)^{0.8},
$$

where $a=1,7 ; 1,8 ; 1,9$ - for road surfaces reinforced with SD-20, SD-30, SD40 geogrids with conditional deformability indicators $E^{\prime}(\varepsilon) 350,525,700 \mathrm{kN} / \mathrm{m}$, respectively, also meeting the requirements of the table $1 ; a=1,0$ - for non-reinforced road clothes.

Table 1 - Characteristics of regulated parameters of polymer reinforcing materials when used in road structures

\begin{tabular}{|c|c|c|c|}
\hline $\begin{array}{c}\text { № } \\
\text { in order }\end{array}$ & Parameter & Parameter characteristics & Regulation \\
\hline \multicolumn{4}{|c|}{ Mechanical properties of polymer reinforcing materials } \\
\hline 1 & $\begin{array}{c}\text { Relative strength of } \\
\text { nodal joints } R_{G R}\end{array}$ & Identification parameter & $\begin{array}{c}\text { Not lower } 50 \% \\
\text { from } R_{R}\end{array}$ \\
\hline 2 & $\begin{array}{c}\text { Conditional index of } \\
\text { deformability in the } \\
\text { material plane } G_{R}\end{array}$ & $\begin{array}{c}\text { Identification parameter that affects } \\
\text { the effectiveness of the application }\end{array}$ & $\begin{array}{c}\text { Not lower } 20 \% \\
\text { from } R_{R(\varepsilon)}\end{array}$ \\
\hline
\end{tabular}

The main functions and properties of geosynthetic materials of the company "Geksa" are presented in [2].

The permissible voltages are determined by the dependence:

$$
\sigma_{\text {доn }}=\frac{\pi \cdot \gamma_{o \partial} \cdot h_{o \partial}+\frac{\pi \cdot c}{\operatorname{tg} \varphi}}{\operatorname{ctg} \varphi \cdot \varphi-\frac{\pi}{2}}+\lambda_{\text {од }} \cdot h_{o \partial},
$$

where $\gamma_{o d}$ - share of the pavement, MN $/ \mathrm{m}^{3} ; c$ - specific adhesion of the Foundation soil, MPa; $\varphi$ - angle of internal friction of Foundation soil, degrees; $h_{o \partial}-$ thickness of the pavement, $\mathrm{m}$. 


\section{Results and discussion}

Features of work production technology. The technology and organization of the construction process in the application of reinforcement, including the preparation of the object, the scheme of the organization of the working area during the work, the organization of labor, quality control and safety, are subject to the general rules for the production of earthworks and road surface construction. When performing work, you should follow the requirements of [3], SNiP 12-03-2001, SNiP 12-04-2002, VSN 8-89, VSN 19-89, VSN 37-84, as well as the provisions of paragraphs 2.16, 2.17 [1].

Features of the production technology are associated with the introduction of an additional operation for laying a geogrid and the introduction of additional requirements for the performance of work on the device of the base layer located directly above the geogrid. The general technological scheme of production of works at new construction is presented in Figure 2, at reconstruction in Figure 3.

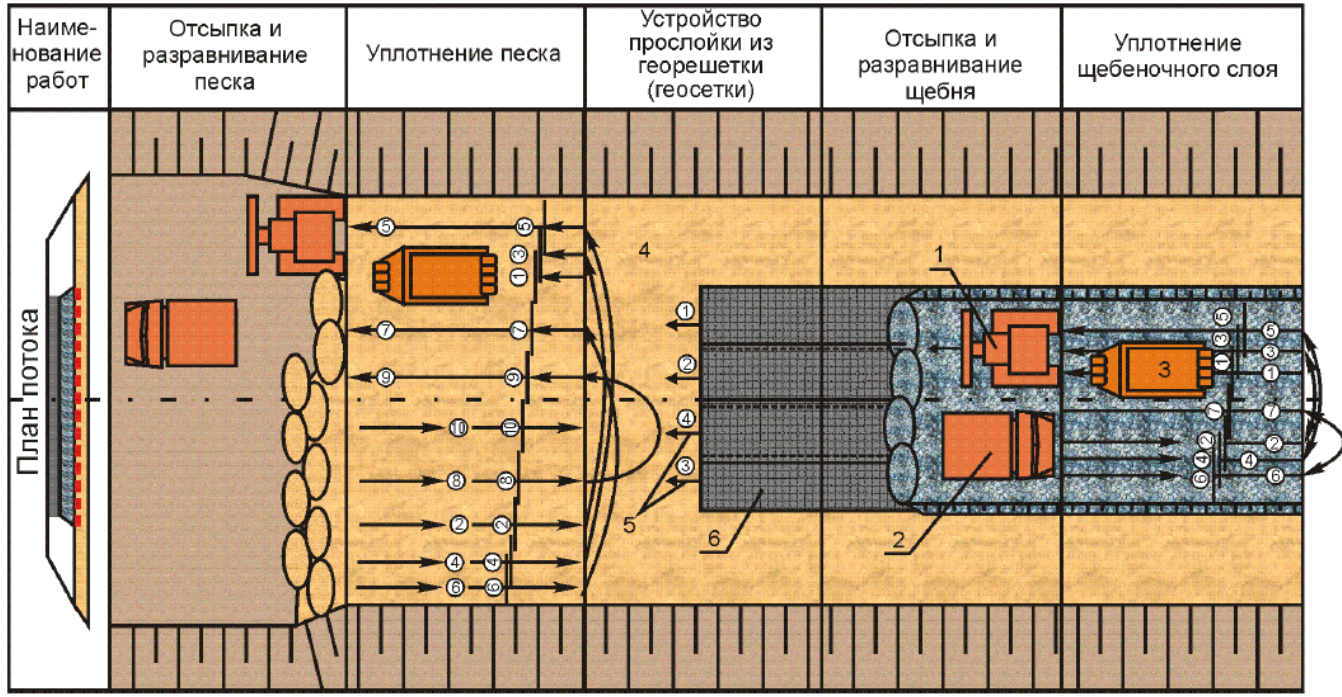

Figure 2 - Technology of work during new construction [6]

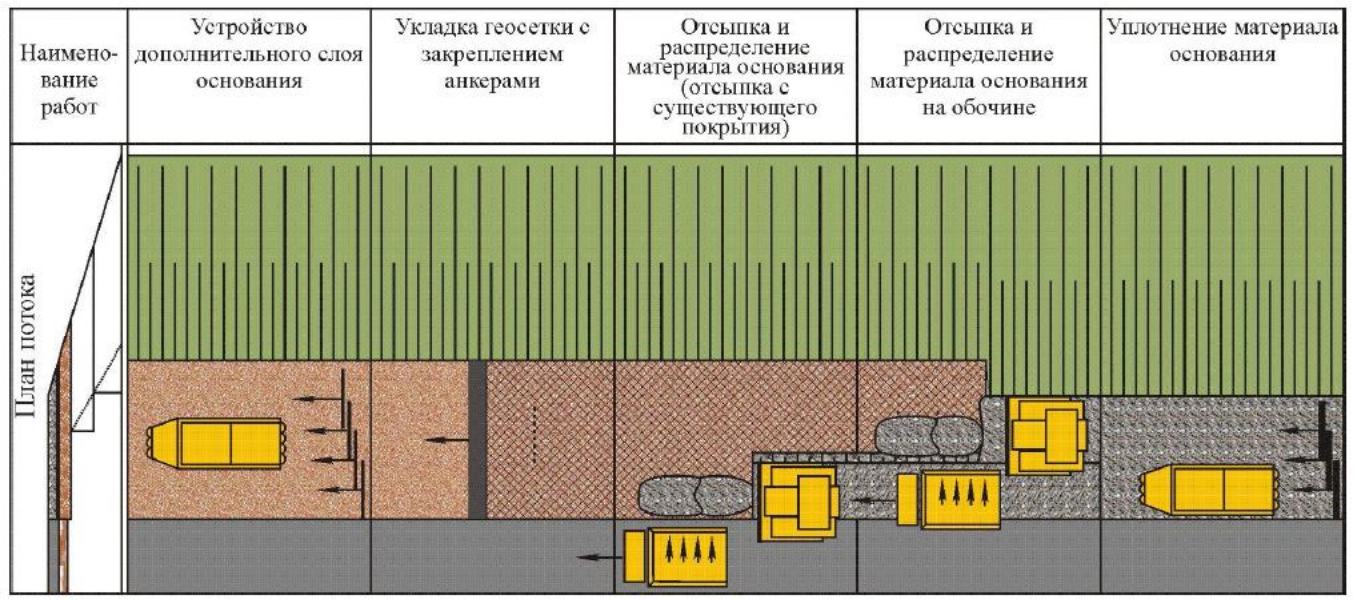

Figure 3 - Tthe Technology of production of works for widening (reconstruction) [6] 
However, in some cases, to save the design position of the geogrid with the possible influence of technological loads encountered during the dumping and spreading of the overlying layer (the beginning of the roll, dumping material from an existing pavement in the widening), and also with strong wind influences, the geogrid can be secured by anchors in figure 4 . The location of anchors with the different methods of device overlying layer shown in figure 4 (anchors are 10-15 m in length with a decrease in this distance, in the case of the device widening to $6 \mathrm{~m}$ at the edge of the leaf that is closest to the direction of dumping of the overlying layers; at the beginning of the roll and in places overlapping coils set of 3 anchor width, in other places -2 anchor width).
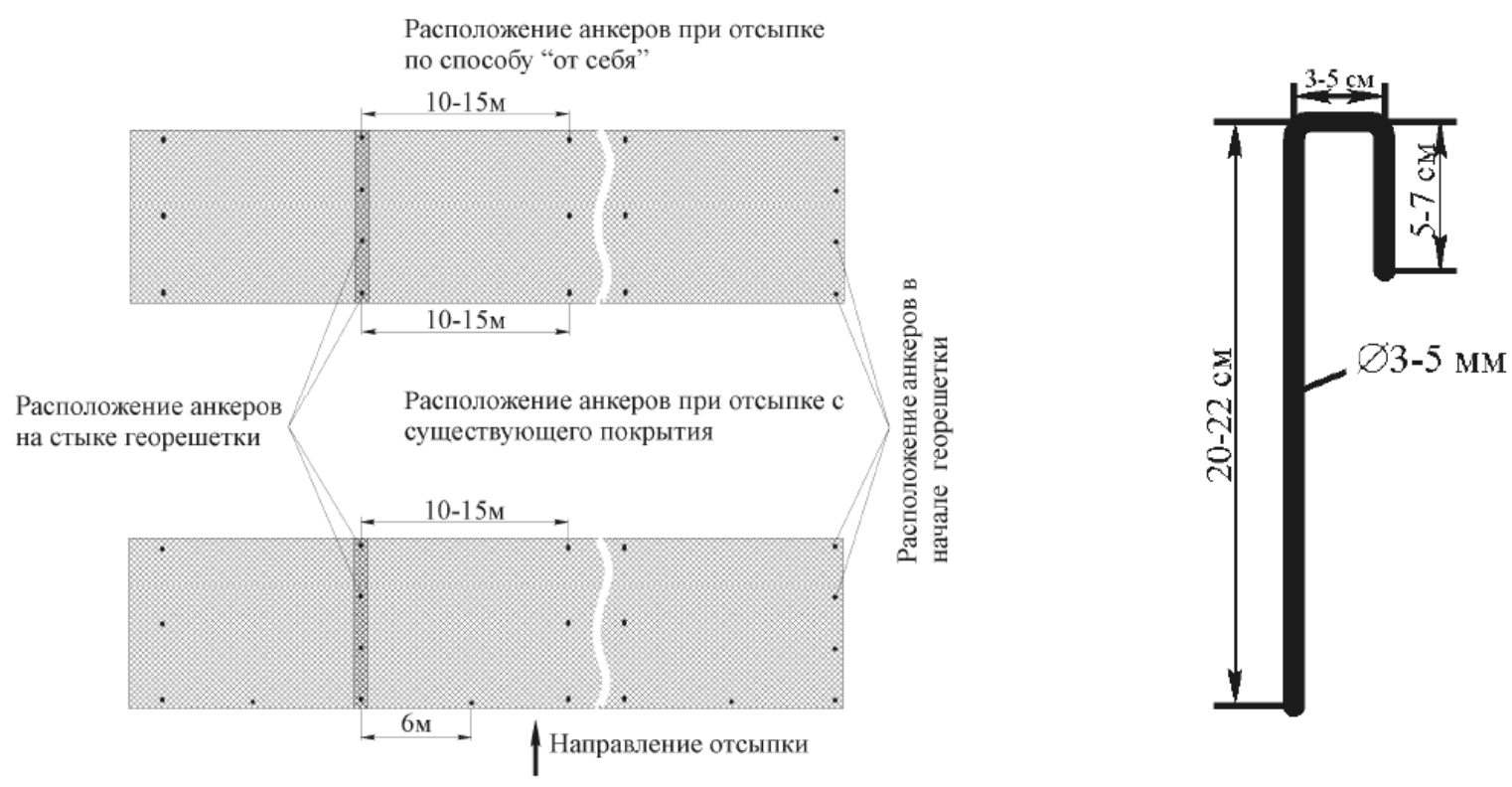

Figure 4 - Technology of work arrangement of anchors (left), anchor design (right). [7]

Laying of the geogrid is performed on a leveled and compacted soil base (sand additional layer of the base) by rolling the roll with periodic (after 10-15 m) alignment of the web and its light tension without the formation of folds (Figure 5,a). As a rule, fixing the geogrid to the underlying layer is not required and undesirable, since it prevents the tension of the web during the formation of a "wave" in the process of filling the overlying layer (Figure 5, d, p.7.4 [1]).

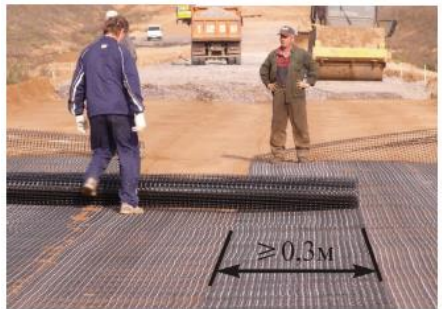

a)

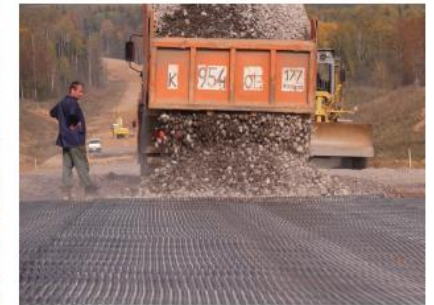

b)

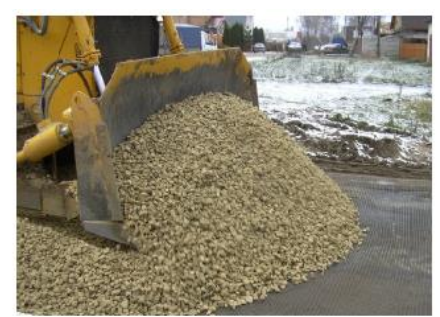

c)

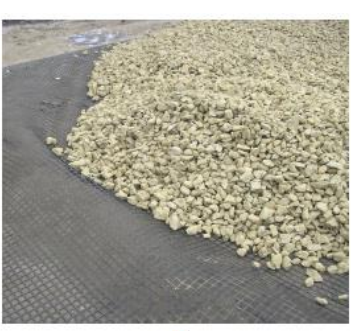

d)

Figure 5 - Separate working operations when reinforcing road surfaces:

$\mathrm{a}$ - laying a geogrid; $\mathrm{b}$ - filling the material of the supporting base; $\mathrm{c}$ - leveling the material according to the method «from yourself»; $d$ - formation of a «wave» before the leveled layer [7] 
Overlap of the canvases along the length and width of at least $30 \mathrm{~cm}$. The direction of the ceiling prescribed with respect to the direction of backfilling and leveling of the material of the overlying layer for elimination of "scoring" the paintings on the ceiling (when dumping on the way from the end of the canvas fill layer is positioned over the beginning of the next leaf; when dumping from an existing cover in case the device widening near the side dumping feature painting above).

The geogrid is laid on the width of the base layer with a margin of at least the thickness of the granular material layer plus $0.1 \mathrm{~m}$ in each direction.

Filling on the laid geogrid of the large-fraction material of the base is carried out according to the method "from yourself" (Figure 5,b and 5,c). Basic terms the device of the base layer is to prevent built - in transport on the exposed surface of the fabric, the gradual leveling of stacked base material in several passes with successive sliding of the base material to the geogrid. When a wave is formed (Figure 5,d), the geogrid should be tensioned. In the process of sliding it is recommended to respect a minimum distance along the stream between the operations on the device layer of the base and rolling rolls (but not closer than $20 \mathrm{~m}$ ) to provide more tension geogrids. The base material must be poured onto the geogrid during the work shift.

When performing works according to paragraphs 7.3 and 7.4 [1], the quality of the laid canvases is visually evaluated. Defects in appearance are recorded (breaks, breaks, other violations of the continuity of edges and nodes, skewed cells, the presence of inclusions, dirt, and the presence of kinks or traces of kinks on the edges, the evenness of the edges).

Also fixed the overlap of adjacent cloths in width and length, the length of material per roll and width, their compliance documents (as marked on the rolls, according to the passport on the batch of material). According to the results of the control, an act for hidden work is drawn up.

Conducting a survey of the condition of road surfaces under dynamic impact, as well as studying the design of road surfaces under static impact of transport load, will make it possible to predict subsequent repairs of the highway $[4,5]$.

\section{Conclusion}

The use of geosenthetic materials has a positive effect on the condition of the roadbed and road surface, especially in the conditions of increased traffic load in recent years. The completed works will allow in the future reducing the cost of maintenance and operation of the highway, as the design of the road surface will last much longer when operated in difficult natural and climatic conditions of our country.

\section{References:}

1. ODM 218.5-002-2008 Metodicheskie rekomendatsii po primeneniyu polimernykh geosetok (georeshetok) dlya usileniya sloev dorozhnoy odezhdy iz zernistykh materialov [Methodological recommendations for the use of polymer geogrids to strengthen the layers of road pavement made of granular materials], Moscow, Rosavtodor, 2008, 99. (in Russ.) 
2. Sh. V. Yunusov, I. S. Bondar. Primenenie geosinteticheskikh materialov v nasypyakh na slabykh gruntakh [The use of geosynthetics in embankments on soft soils]. Materialyi XLII Mezhdunarodnoy nauchno-prakticheskoy konferentsii «Innovatsionnyie tehnologii na transporte: obrazovanie, nauka, praktika» KazATK M. Tyinyishpaeva = Proceedings of the XLII International scientific-practical conference KazATK. M. Tynyshpayev on the theme "Innovative technologies in transport: education, science, practice", 2018, 147-157. (in Russ.)

3. SNiP RK 3.03-09-2006 Avtomobil'nye dorogi [Automobile roads], Astana, 2006. (in Russ.)

4. I.S. Bondar, J. D. Madiev. Otsenka sostoyaniya dorozhnykh odezhd pri dinamicheskom vozdeystvii [Assessment of the state of road surfaces under dynamic impact]. Sbornik materialov XIX ezegodnoi nauchnoi studencheskoi konferentsi. Chast $1=$ Collection of materials of the XIX annual Republican Scientific Student Conference. Part I. 2019, 417-421.

5. I. S. Bondar, D. T. Aldekeyeva, Zh. B. Bekasyl. Issledovanie konstruktsiy dorozhnoy odezhdy pri staticheskom vozdeystvii nagruzki [Investigation of pavement structures under static load]. Vestnik KazNITU= Bulletin of KazNITU 2021, 1(141), 21-26.

6. Spravochnaya entsiklopediya dorozhnika. I TOM. Stroitel'stvo i rekonstruktsiya avtomobil'nykh dorog. Pod redaktsiyey zasluzhennogo deyatelya nauki i tekhniki RSFSR, d-ra tekhn. nauk, prof. A.P. Vasil'yeva. MOSKVA 2005 [Departmental Building Standards (VBS 197-91) Design instructions for rigid road clothing. Moscow 2000] (in Russ.).

7. Vedomstvennyye Stroitel'nyye Normy (VSN 197-91) Instruktsiya po proyektirovaniyu zhestkikh dorozhnykh odezhd. Moskva 2000 [Reference encyclopedia of the road builder. I. VOLUME. Construction and reconstruction of highways. Edited by Honored Worker of Science and Technology of the RSFSR, Dr. Sciences, prof. A.P. Vasiliev. MOSCOW 2005] (in Russ.).

\title{
М.Я. Квашнин ${ }^{1}$, И.С. Бондарь ${ }^{1 *}$, Д.Т. Алдекеева ${ }^{1}$, Н.С. Имамбаев ${ }^{2}$
}

\author{
${ }^{1}$ Академия логистики и транспорта, г. Алматы, Казахстан \\ ${ }^{2}$ Северо-Казахстанский университет им. М. Козыбаева, Петропавловск, Казахстан
}

Информация об авторах:

Квашнин Михаил Яковлевич - кандидат технических наук, профессор, Академия логистики и транспорта, Алматы, Казахстан

https://orcid.org/0000-0002-3969-9299, e-mail: kvashnin_mj55@mail.ru

Бондарь Иван Сергеевич - кандидат технических наук (BАК РФ), Ph.D (MOH PК), ассоциированный профессор, Академия логистики и транспорта, Алматы, Казахстан

https://orcid.org/0000-0001-7376-5643, e-mail: ivan_sergeevich_08@mail.ru

Алдекеева Динара Танашбековна - кандидат технических наук, ассоциированный профессор, Академия логистики и транспорта, Алматы, Казахстан

https://orcid.org/0000-0001-7376-5643, e-mail: aldekeeva69@mail.ru

Имамбаев Нурлан Сальтаевич - магистр технических наук, старший преподаватель, Северо-Казахстанский университет им. М. Козыбаева, Петропавловск, Казахстан

https://orcid.org/0000-0003-3104-8878, e-mail: imambaevn@mail.ru

\section{МЕТОДИКА УПРОЧНЕНИЯ НЕЖЕСТКИХ ДОРОЖНЫХ ОДЕЖД}

\begin{abstract}
Аннотация. $B$ статье рассмотрена методика упрочнения земляного полотна и нежестких дорожных одежд, на участках со слабыми грунтами. Применение геосентетических материалов положительно сказывается на состоянии земляного полотна и дорожной одежды, особенно в условиях увеличившейся в последние годы транспортной нагрузки. Выполненные работы позволят в будущем сократить затраты на содержание и эксплуата-
\end{abstract}


цию автомобильной дороги, так как конструкция дорожной одежды прослужит намного дольше при эксплуатировании в сложных природно-климатических условиях нашей страны.

Ключевые слова: полимерные георешетки (геосетки), проектирование и технология строительства дорожных одежд.

\author{
М.Я. Квашнин ${ }^{1}$, И.С. Бондарь ${ }^{1 *}$, Д.Т. Алдекеева ${ }^{1}$, Н.С. Имамбаев ${ }^{2}$ \\ ${ }^{1}$ Логистика және көлік академиясы, Алматы, Қазақстан, \\ ${ }^{2}$ М.Қозыбаев атындағы Солтүстік Қазақстан университеті, Петропавл, Қазақстан
}

\begin{abstract}
Авторлар туралы мәліметтер:
Квашнин Михаил Яковлевич - техника ғылымдарының докторы, профессор, Логистика және көлік академиясы, Алматы, Қазақстан

https://orcid.org/0000-0002-3969-9299, e-mail: kvashnin_mj55@mail.ru

Бондарь Иван Сергеевич - техника ғылымдарының кандидаты (РФ ЖАК), Ph.D (ҚР БҒМ), қауымдастырылған профессор, Логистика және көлік академиясы, Алматы, Қазақстан https://orcid.org/0000-0001-7376-5643, e-mail: ivan_sergeevich_08@mail.ru

Алдекеева Динара Танашбекқызы - техника ғылымдарының кандидаты, қауымдастырылған профессор, Логистика және көлік академиясы, Алматы, Қазақстан

https://orcid.org/0000-0001-7376-5643, e-mail: aldekeeva69@mail.ru

Имамбаев Нұрлан Салтайұлы - техникалық ғылымдар магистры, аға оқытушы, М.Қозыбаев атындағы Солтүстік Қазақстан университеті, Петропавл, Қазақстан

https://orcid.org/0000-0003-3104-8878, e-mail: imambaevn@mail.ru
\end{abstract}

\title{
ТЕГІС ЖОЛ КИІМІН ӘДІСТІ КУАТТАНДЫРУ
}

Андатпа. Мақ̧алада топырақтары әлсіз аймақтарда жол төсеніштерін және қ̧атты емес жол төсемдерін нывайту әдісі қуарастырылады. Геосинтетикалық материалдарды пайдалану жер асты құабатының және жол жабынының жавдайына, әсіресе сонзы жылдардавы көлік жүктемесінің артуы жавдайында оң дсер етеді. Жүргізілген жұмыстар болашақта жолды күтіп ұстаува және пайдаланува кететін шызындарды азайтува мүмкіндік береді, өйткені жабынның құрылысы еліміздің күрделі табиги-климаттық жавдайында жұмыс істегенде әлдеқайда ұзавырақ болады.

Түйін сөздер: полимерлі геогридтер (геогридтер), төсемдерді жобалау және салу технологиясы. 